Holland, Douglas A. 1993 (May). Somerset West Community Health Centre: Report on Community Profile, Clients and Services Input to Needs Assessment. Ottawa: SWCHC.

Lanphier, Michael, and Oleh Lukomskyj. 1994. "Settlement Policy in Australia and Canada." In Immigration and Refugee Policy: Australia and Canada Compared, edited by Howard Adelman et al. Carlton, Toronto and Buffalo: University of Melbourne and University of Toronto Presses.

Lanphier, Michael, Janet McLellan, and Edward Opoku-Dapaah. 1995. "Models for Newcomer Resettlement." Submitted in text proposal.

Lynam, Judith M. 1985. "Support Networks Developed by Immigrant Women." Social Science of Medicine 21, no. 3: 327-33.

McLellan, Janet. 1995. “Cambodian Refugees in Ontario: An Evaluation of the Resettlement and Adaptation." Toronto: Centre for Refugee Studies/York Lanes Press.

McLellan, Janet, and Anthony H. Richmond. 1994. "Multiculturalism in Crisis: A Postmodern Perspective on Canada." Ethnic and Racial Studies 17, no. 4: 662-83.

Ministry of Health. 1993a (June). "Community Health Centres in Ontario: A Picture of Health." Ontario Ministry of Health, Community Health Branch.

- . 1993b (June). "Community Health Centre Program, Ontario Ministry of Health: Strategic Directions 1993/94-1996/97." Strategic Planning and Evaluation Project.

Opoku-Dapaah, Edward. 1993. “Directory of African Community Groups in Metropolitan Toronto." Toronto: Centre for Refugee Studies/York Lanes Press.

- 1995. "Somali Refugees in Toronto: A Profile." Toronto: Centre for Refugee Studies/York Lanes Press.

Reitz, Jeffrey. 1988. "The Institutional Structure of Immigration as a Determinant of Inter-racial Competition: A Comparison of Britain and Canada." International Migration Review 22, no. 1: 117-46.

Richmond, Anthony H. 1969. "Sociology of Migration in Industrial and Postindustrial Societies." In Sociological Studies 2: Migration, edited by J. Jackson. Cambridge: Cambridge University Press.

-1994. Global Apartheid: Refugees, Racism and the New. World Order. Toronto, New York and Oxford: Oxford University Press.

Wong, D. 1989. "The Semantics of Migration." Sojourn 4, 2-7.

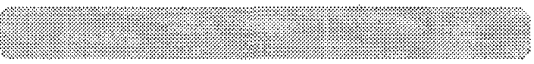

\title{
Neo-Liberal Strategies to Cut Costs in Settlement Services: Cost Recovery and Devolution
}

\author{
John Morris
}

\section{Abstract}

The author considers the range of settlement services funded by Citizenship and Immigration Canada (CIC) tracing the relative costs of settlement services in both Quebec and the rest of Canada. Government cost cutting and recovery strategies applied to settlement services are reviewed against an explanation of neo-liberalist ideology as it has been interpreted by the Federal government (1993-1997). Some of the arguments put forward against cost recovery are also reviewed.

\section{Précis}

L'auteur explore l'éventail des services d'intégration mis en place par Citoyenneté et Immigration Canada (CIC) en retraçant les coûts relatifs des services d'intégration au Québec et dans le reste $d u$ Canada. On passe en revue l'application des stratégies de compressions et de recouvrement budgétaires gouvernementales au cas spécifique du secteur des services d'intégration, ce qui permet de procéder à une explication de l'interprétation de l'idéologie néo-libérale à laquelle procéda le gouvernement fédéral (1993-1997). Certains des arguments mis de l'avant en matière de recouvrements de coûts sont aussi présentés.

\section{Neo-Liberalism}

The Canadian government started to follow neo-liberal economic policies in the mid-1980s. "Neo" preceding "liberal" means a new kind of liberalism. The old kind was the liberal school of economics that became famous after the publication of English economist Adam Smith's, The Wealth of Nations in 1776. Liberal economics advocated the

John Morris, PhD, is Assistant Professor of Geography, Nipissing University, North Bay. abolition of government intervention in economic matters. Free trade was seen as the best way for a nation's economy to develop; no restrictions on manufacturing, no barriers to commerce, and no tariffs. Such ideas were "liberal" in the sense of no controls. When applied to individuals it encouraged free enterprise and free competition without limits on profits or capital accumulation as would be argued for by varying stripes of socialists.

Economic liberalism prevailed in Canada and North America through the 1800 s and early 1900 s. With the Great Depression of the 1930s economist John Maynard Keynes was able to successfully challenge liberalism as the best policy for capitalists. $\mathrm{He}$ argued that full employment is necessary for capitalism to grow and it can be achieved only if governments intervene to increase employment. Through the post-World War II period North American economies grew quickly because of the age structure and export opportunities elsewhere. From the 1970 s onward, however, with an older age structure and increased world competition, profits shrank inspiring the corporate elite to revive economic liberalism, making it thus new or neo-liberalism.

Four important concepts central to neo-liberalism are the following: cutting public expenditure for social services like education and health care; deregulation of government activities that might diminish profits; privatising government run businesses, for example utilities, hospitals; and eliminating the concept of "the public good" or "community" and replacing it with "individual responsibility." These are the concepts that are the basis for most governmental decision-making in Canada. 


\section{Deficit Fighting by the Federal Government}

In the mid-1990s debt in the Federal government has become a terrifically serious concern. In 1996 government debt equalled 100 percent of the country's total output; total debt is over $\$ 550$ billion. The only time in Canada's history the ratio of debt to economic output was as high was in 1946 at the end of the Second World War. A concerted effort was made to reduce debt to GDP until 1974 (though the period did also see ongoing economic expansion) when debt reached a low of 20 percent of GDP (Turner 1996). From here politicians began to spend wildly, and the rate of economic growth began to decrease to the point where very serious government spending cutsand extreme neo-liberal policies-are now seen as the only way to bring deficits and debt under control.

Canadians grudgingly support the need to reduce the deficit in a neo-liberal way. Social policies and programs built during the Keynesian era, an era that sought to rectify the injustices of capitalism, are being dismantled. Policies such as universalism-that all should receive the same fundamental services without regard to personal income-and equality in service-that all should receive the same standards of service-are being abandoned. For those who lived through the Great Depression and World War II these values were deemed a sacred trust. With an aging population, however, it appears that the experiences of hardship and values developed through hardship are waning in popular sentiment. For this older population generous social policies were sacred. Times and values, it appears, have changed. A poll conducted at year's end in 1996 reported that a majority of Canadians expect that within the next decade Canada will have a two-tiered (public and private) health care system and private universities; two institutions that previous generations successfully avoided (Wilson-Smith 1997). The neoliberal agenda is being implemented through the Federal budgets, the 1996 February budget is a case in point.

\section{The Budget of 1996 as an Example of Neo-Liberal Policy \\ Implementation}

When arriving in office in late 1993 the Liberal government inherited an annual deficit of $\$ 42$ billion from the Conservatives. By 1997 they expect to shrink that operating deficit to $\$ 17$ billion (Wilson-Smith 1997). Much of the deficit reduction program was announced the previous year in the government's February budget of 1995. Beyond modest budget cuts that included a 9-percent reduction in government program spending by 1996-97, the Government implemented and proposed tax and revenue increases of 6.5 billion in the period from 1994 to 1998 . One and a half billion of this is coming from user fees and cost recovery items such as the Right of Landing Fee (ROLF) for immigrants. The result for Canadians is that the nature of living and doing business in Canada is changing (Corcoran 1995).

Another dimension of the neo-liberal ideology is to reduce the size of government. In the February budget of 1996 the Government proposed the devolution of powers to the provinces in forestry, mining, labour market training, and recreation. Further, it promised to negotiate and dialogue in other areas such as social policy programming (e.g., child care and health care) that had previously been a nonnegotiable Federal domain. One of the purposes of devolution is to save the devolving organisation money. A pattern that can be identified is that increased powers through devolution also means decreased funding. For example transfer payments to the provinces for health, social services and education have become less tied but are also scheduled to see reductions in funding by nearly one third or $\$ 6$ billion by $1997-98$ from about $\$ 18$ billion in 1995 (Western Report 1995).

Devolution is seen by the Federal Government as the most hands-off kind of arrangement it can foresee in service delivery. On a continuum of Federal government involvement devolution is found at one extreme. At the other is complete government control. In between are different configurations of partnerships and consultations (Rodal 1995, 13). To the Federal government devolution means the passing along of service delivery, program/service design, evaluation and adjustment to some other party while the government retains control of policy development, standards, monitoring and oversight (ibid.).

\section{Bibliography}

Brown, Jim. 1996. “Unity Displaces Economics on Liberal Agenda. Throne Speech Puts Onus for Job Creation on Business. Chretien's Proposals Echo Mulroney Constitutional Talks." Canadian Press Newswire, February 27.

Corcoran, Terence. 1995. "For Canada, this Budget is not the End." Globe and Mail, February 28, B2.

Dolan, Marty. 1997. Conversation by telephone with the author from his Winnipeg office, January 15.

Citizenship and Immigration Canada (CIC). 1995. A Broader Vision: Immigration Plan 1996 Annual Report to Parliament. Hull: Supply and Services. Cat. No.: Ci1-1996.

-1995a. Attachment 1, Current Settlement Allocation Model. Hull: Settlement Devolution Project Staff.

- 1996 (June). Round II Consultations on Settlement Renewal: Finding a New Direction for Newcomer Integration. Internet: http:// cicnet.ingenia.com /english/ pub/9605erd2.html., (downloaded January 3, 1997).

Communiqué. 1996. "La Table de concertation des organismes de Montreal au service des réfugiés regroupe 82 organismés d'aide aux réfugiés et nouveaux arrivants." Montréal, le 15 octobre.

Eels, Ron. 1995. Conversation by telephone. Department of Immigration and Citizenship, Ottawa, February.

Financial Post Daily. 1996. "Doubts Remain Whether the Budget Will Ever Be Balanced." Vol. 9., no. 20, March 7, B1-B2.

Lett, Dan. 1995. "Marchi Caught Between Rock and Hard Place." Winnipeg Free Press, May 2.

. 1995a. "Dump Head Tax, Pagtakhan Says." Winnipeg Free Press, May 2. 